\title{
Screening of some catalytic activities of mature berries of Solanum aethiopicum cultivar "Klongbo"
}

\author{
Fagbohoun Jean Bedel 1, ${ }^{*}$, Aké-assi Yolande 2, Djina Yves ${ }^{3}$, N'guessan Kouakou Alban ${ }^{1}$ and Kouamé Lucien \\ Patrice ${ }^{3}$ \\ ${ }^{1}$ Department of Biochemistry-Genetics, University Peleforo Gon Coulibaly, Korhogo, Côte d'Ivoire. \\ ${ }^{2}$ Central Laboratory for Food Hygiene and Agribusiness, LANADA, Abidjan, Côte d'Ivoire. \\ ${ }^{3}$ Department of Food Science and Technology, University Nangui Abrogoua, Abidjan, Côte d'Ivoire.
}

Magna Scientia Advanced Biology and Pharmacy, 2021, 01(02), 035-041

Publication history: Received on 29 December 2020; revised on 07 January 2021; accepted on 09 January 2021

Article DOI: https://doi.org/10.30574/msabp.2021.1.2.0024

\begin{abstract}
Aubergines of the Solanum aethiopicum cultivar "Klongbo" are widely cultivated and consumed by the Ivorian population. However, their post-harvest conservation is problematic. In order to prevent their post-harvest degradation, this study initiates the screening of enzymatic activities responsible for hydrolysis and oxidation activities in the berries of Solanum aethiopicum cultivar "Klongbo". Among the enzymatic activities tested, phosphatases, N'Acethylglucosaminidase, dopamineoxydase and pyrocatecholoxydase were the predominant enzymatic proteins. The optimum hydrolysis and oxidation conditions in terms of $\mathrm{pH}$ and temperature are listed as follows: phosphatases (pH

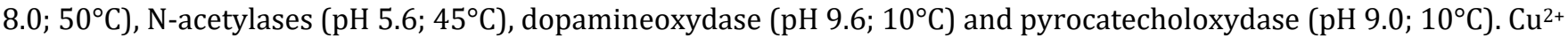
ions inhibit all tested enzymatic activities and especially $\mathrm{Zn}^{2+}$ ions for polyphenoloxidase activities. EDTA has an inhibitory effect on phosphatase and N'acetylase activities. SDS has an inhibitory effect on dopamineoxydasic, pyrochatecholoxydasic and phosphatasic activities. On the other hand, it has no effect on N'Acethylglucosaminidasic activities.
\end{abstract}

Keywords: Solanum aethiopicum; Polyphenoloxidase; Phosphatase; N'Acethylglucosaminidase

\section{Introduction}

The aubergine is a vegetable plant of the Solanaceae family, cultivated for its fruit and leaves consumed as a vegetable. It is a fruit-vegetable with economic importance in Mediterranean countries and Asia [1]. It is also found in America and Africa. It can be cultivated in a wide variety of climates (temperate, tropical dry or humid). Thus, it contains many types of cultivars that vary according to the colour, size and shape of the fruit [2]. Many local or introduced varieties, belonging to different species, such as Solanum aethiopicum gilo "N'drowa", Solanum aethiopicum "Klongbo" and Solanum macrocarpon "Gbokouman", are cultivated in small, generally urban and peri-urban market gardens in Côte d'Ivoire [3]. According to Lester et al., [4], Solanum aethiopicum anguivi is a bitter aubergine species much appreciated by the populations of the centre of the Ivory Coast, where it is commonly known in the Baule language as "Klongbo". This variety can reach a height of $96.3 \mathrm{~cm}$ to $106.3 \mathrm{~cm}$ with clustered inflorescences ( 3 to 9 flowers). Solanum aethiopicum "Klongbo" is the species that bears the largest number of fruits on the stem with very small diameters and elongated shapes, the average weight of the fruits varying from 16 to $20 \mathrm{~g}$ [5]. Vegetables play an important role in human nutrition because of their content of vitamins, minerals and other nutritional compounds that contribute to better health. For example, the consumption of aubergine leaves and fruits provides the body with carotenes, various vitamins (B and C), folic acid, minerals and protein [6, 7]. With regard to its energy intake, aubergine provides about 18 kilocalories per 100 $\mathrm{g}$, as do tomatoes, chicory and lettuce. It is rich in water (more than $92 \%$ on average). And its energy content remains

\footnotetext{
${ }^{*}$ Corresponding author: Fagbohoun jean bedel

Department of Biochemistry-Genetics, University Peleforo Gon Coulibaly, Korhogo, Côte d'Ivoire.
} 
limited. Despite its very high consumption, the marketing of aubergines remains informal and their post-harvest conservation remains a real problem. In Côte d'Ivoire, the north of the country has the highest percentage of production, but losses are estimated at $60 \%$. In fact, the attack of micro-organisms and injuries caused during the harvest lead to many losses during harvesting, storage and conservation of these fruit vegetables. On a chemical level, these losses are caused by free radicals formed from quinones produced during oxidation reactions catalysed by polyphenoloxydases (PPO) and to a lesser degree by the peroxidases responsible for browning. Although sought after in certain food technologies such as coffee processing, enzymatic browning can lead to loss of nutritional value, discolouration and deterioration of the organoleptic quality of the food $[8,9,10]$. All the damage suffered is the result of mechanical processes (harvesting, storage, conservation) and enzymatic reactions that take place in the cells of Solumun aetiopicum "Klongbô" fruit-vegetable aubergines. This study aims to highlight some major enzymatic activities in this prized variety of aubergine in Ivory Coast and to determine the optimal $\mathrm{pH}$ and temperature conditions for hydrolysis of the predominant activities.

\section{Material and methods}

\subsection{Material}

\subsubsection{Biological material}

The plant material consists of Solanum aethiopicum cultivar "Klongbo" (figure 1). These berries come from a market gardening culture in the town of Korhogo, located in the North of Ivory Coast (632 km from Abidjan, Ivory Coast). They are harvested at the mature stage and sent to the biocatalysis and bioprocessing laboratory of the Nangui Abrogoua University, for the preparation of the raw enzymatic extract.

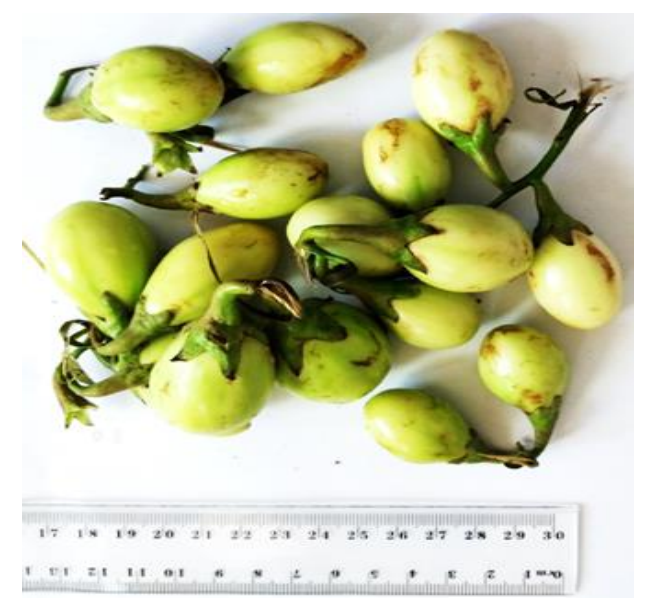

Figure 1 Solanum aethiopicum cultivar "Klongbo"

\subsection{Methods}

\subsubsection{Preparation of the enzymatic crude extract}

Ten (10) grams of Solanum aethiopicum cultivar "Klongbo" were crushed in a blender in the presence of $400 \mathrm{ml}$ of $\mathrm{NaCl}$ $(0.9 \%, \mathrm{w} / \mathrm{v})$. The obtained grinded material was centrifuged at $12500 \mathrm{rpm}$ for $30 \mathrm{~min}$ at a temperature of $4^{\circ} \mathrm{C}$ in a centrifuge HERMECE Z 300K. The supernatant obtained is the raw enzymatic extract of the berries of Solanum aethiopicum cultivar "Klongbo".

\subsubsection{Techniques for determining enzymatic activities}

Measurement of the osidic activities

The osidic activities were determined using the reaction medium consisting of $125 \mu \mathrm{l} \mathrm{NaCl}(0.9 \%), 50 \mu \mathrm{l}$ crude enzyme extract. The mixture was brought to 37 in a water bath for 5 minutes. After pre-incupation, $75 \mu$ l of substrate (xylane, starch, sucrose and carboxymethylcellulose) were added to each tube. This reaction medium was incubated in a water bath for 30 minutes at $37^{\circ} \mathrm{C}$. Then $300 \mu \mathrm{l}$ of a solution of 3,5-dinitrosalicylic acid (DNS) were added to stop the enzymatic reaction [11]. After being heated in a boiling water bath for $5 \mathrm{~min}$, the tubes were cooled to room temperature for 10 $\mathrm{min}$ and $2 \mathrm{ml}$ of distilled water was added. The product was analysed by measuring the optical density at $540 \mathrm{~nm}$. 
Measurement of esterasic and heterosidasic activities

Esterasic and heterosidic activities were determined in a reaction medium containing $125 \mu \mathrm{l}$ of $\mathrm{NaCl}(0.9 \%), 1.5 \mathrm{mM}$ of p-nitrophenyl (phosphate, N'Acethylglucosaminidasic...) and $50 \mu \mathrm{l}$ of crude enzymatic extract. The mixture was incubated at $45^{\circ} \mathrm{C}$ for $10 \mathrm{~min}$. The reaction was stopped by adding $2 \mathrm{ml}$ of $2 \% \mathrm{Na}_{2} \mathrm{CO}_{3}(\mathrm{w} / \mathrm{v})$. Absorbances were measured at $410 \mathrm{~nm}$ using a spectrophotometer. Para-nitrophenol $(p N P)$ was used as standard

\section{Measurement of polyphenoloxidase activities}

The reaction medium consists of $1.1 \mathrm{ml} \mathrm{NaCl}$ (0.9\%), $0.8 \mathrm{ml}$ substrate (dopamine, pyrocatechol, tyrosine, phenylalanine, pyrogaloll) $8 \mathrm{mM}$; $-0.1 \mathrm{ml}$ enzymatic crude extract. This medium was the standard medium. The mixture was incubated at room temperature $\left(25^{\circ} \mathrm{C}\right)$ for $10 \mathrm{~min}$. The optical density reading was taken with a spectrophotometer at $480 \mathrm{~nm}$ against a control containing no crude enzyme extract [12].

A unit of activity has been defined as the amount of enzyme that hydrolyses $1 \mu$ mol of substrate per minute according to the enzyme assay conditions. The specific activity was expressed as a unit of activity per mg of protein.

\subsubsection{Determination of optimum hydrolysis $p H$ values}

The buffers citrate phosphate $20 \mathrm{mM}$ (pH 3.0 to 7.0), sodium acetate $20 \mathrm{mM}$ (pH 3.6 to 5.6), potassium phosphate 20 $\mathrm{mM}(\mathrm{pH} 5.6$ to 8.0 ) and sodium glycine hydroxide $20 \mathrm{mM}(\mathrm{pH} 8.0$ to 10.0) were used for the determination of the optimum hydrolysis $\mathrm{pH}$ of the enzymatic crude extract. The residual activities were determined under standard conditions.

\subsubsection{Determination of optimum hydrolysis temperatures}

The influence of temperature on the enzymatic crude extract was studied at temperatures between 30 and $80^{\circ} \mathrm{C}$ for osidic and $p$-NP (phosphate and N'Acethylglucosamine) activities and between 5 and $45^{\circ} \mathrm{C}$ for polyphenoloxidase activities. The enzymatic activity was determined under standard conditions. It was expressed as a percentage of the maximum activity.

\subsubsection{Effect of certain chemical agents}

To determine the effect of various compounds as possible activators or inhibitors, the enzyme crude extract was preincubated at $37^{\circ} \mathrm{C}$ for 1 hour with the compounds and the activity was determined under the conditions of the enzyme assay. Residual activities were expressed as a percentage of the control without chemical agents

\section{Results}

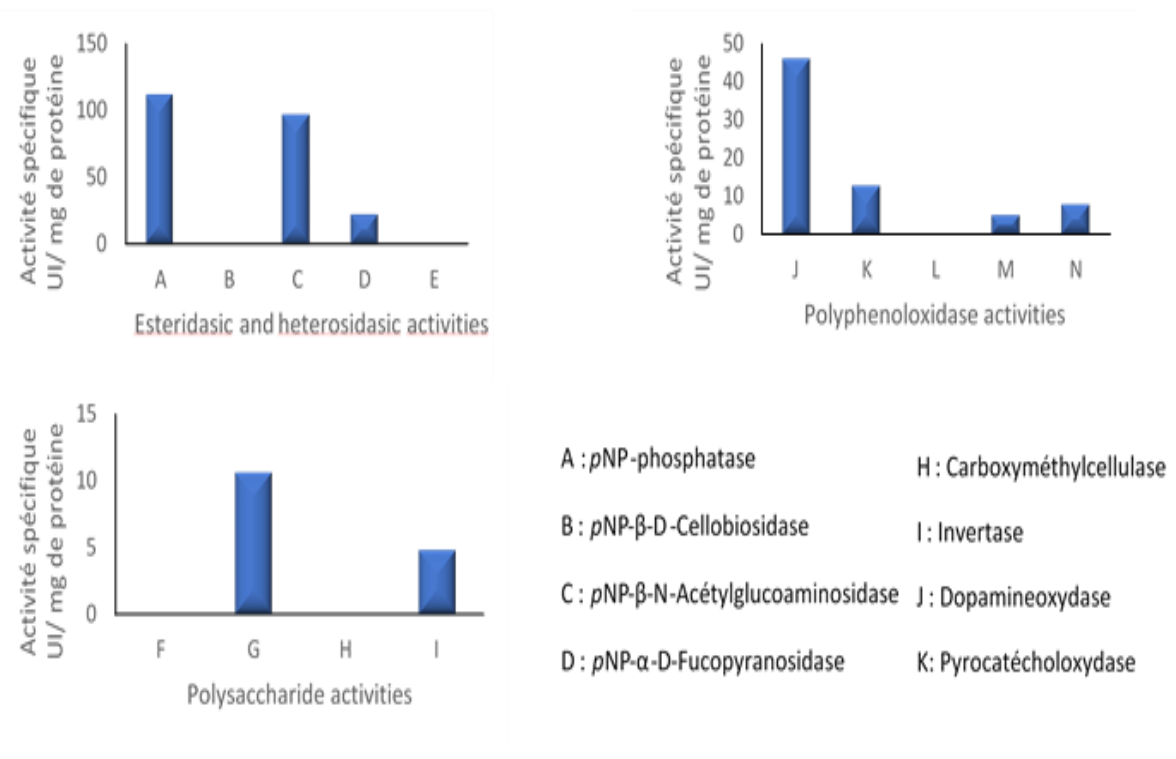

Figure 2 Determination of hydrolytic and oxidase activities of mature berries of Solanum aethiopicum cultivar "Klongbo" 

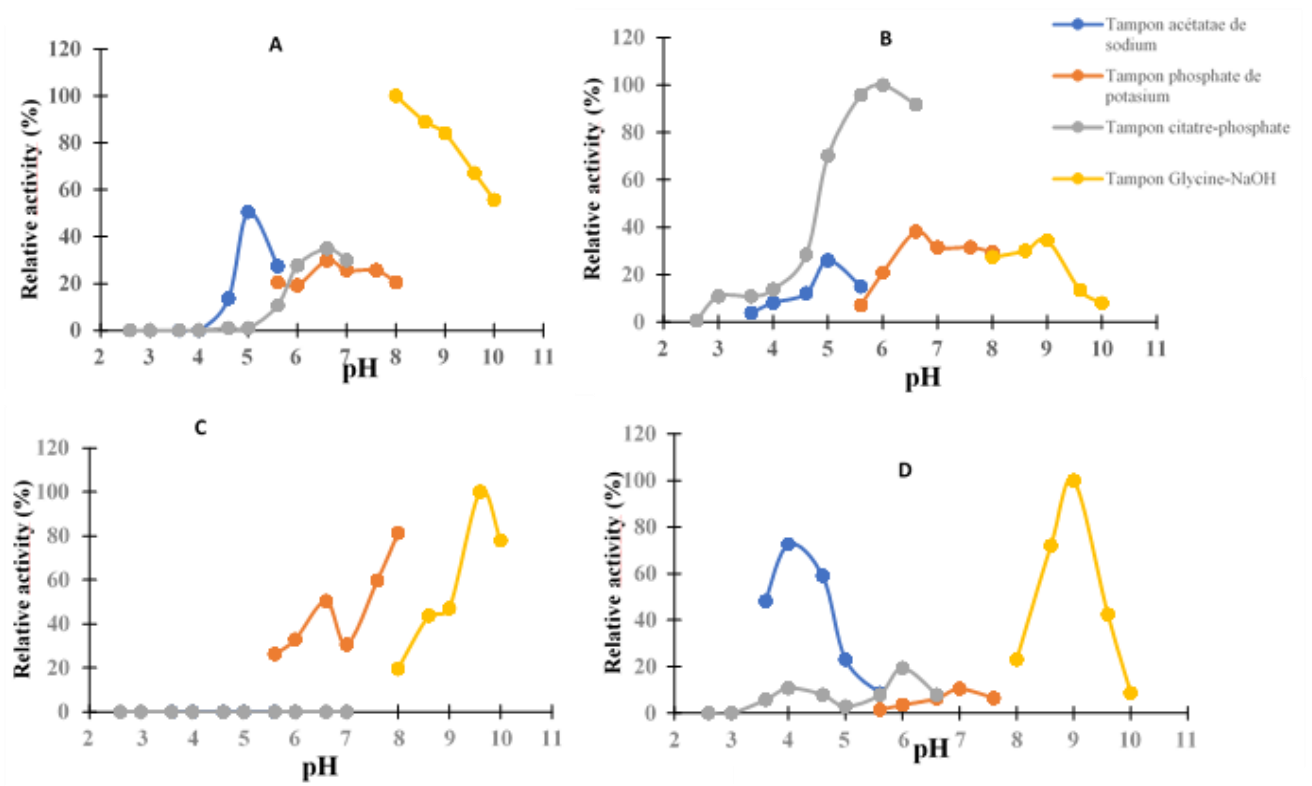

Figure 3 Determination of optimum $\mathrm{pH}$ for hydrolysis and oxidation of mature berries of Solanum aethiopicum cultivar "Klongbo". A: pNP-Phosphatase activity, B: pNP-N'acetylglucosaminidase activity, C: dopamineoxidase activity, D: pyrocatecholoxidase activity.
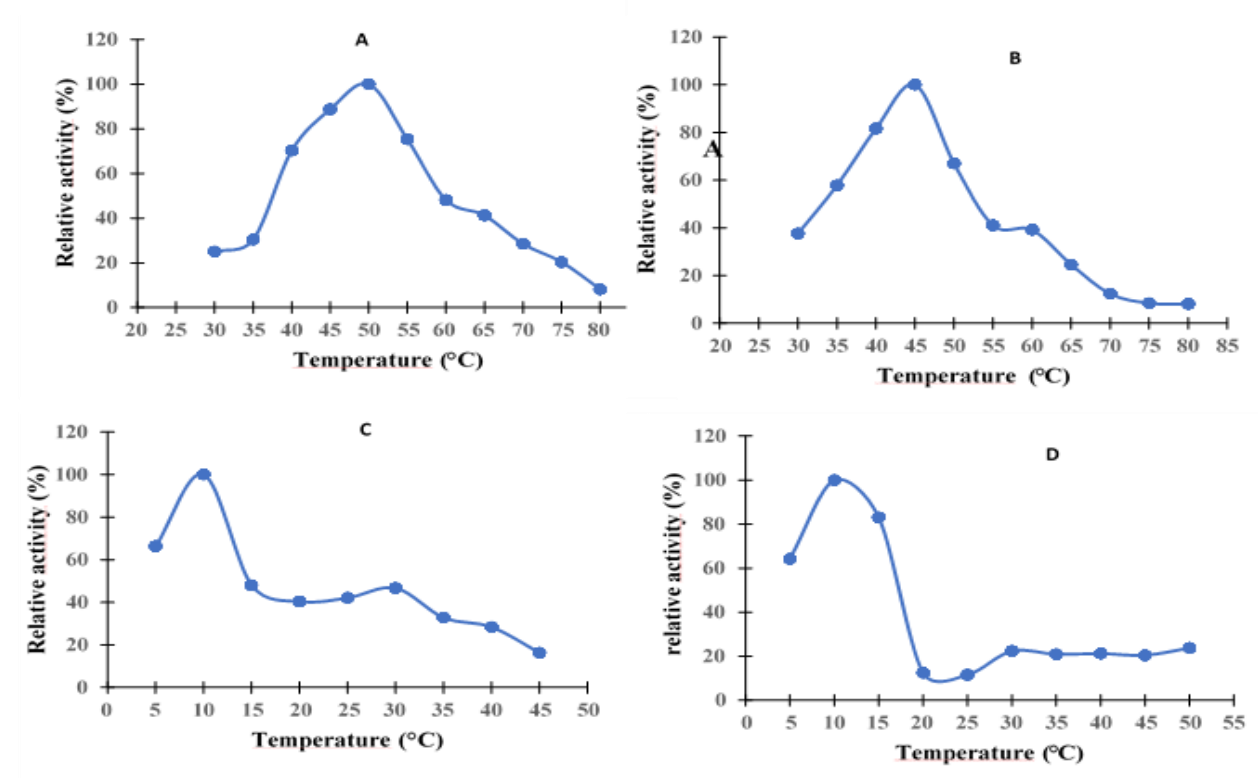

Figure 4 Determination of optimal temperatures for hydrolysis and oxidation of mature berries of Solanum aethiopicum cultivar "Klongbo". A: pNP-Phosphatase activity, B: pNP-N'acetylglucosaminidase activity, C: dopamineoxidase activity, D: pyrocatecholoxidase activity. 
Table 1 Effect of chemical agents on the predominant enzymatic activities of the raw extract of the berry Solanum aethiopicum cultivar "Klongbo".

\begin{tabular}{|c|c|c|c|c|c|}
\hline & $\begin{array}{l}\text { Concentration } \\
\mathrm{s}(\mathrm{mM})\end{array}$ & $\begin{array}{l}p \text { NP- } \\
\text { Phosphatease } \\
\text { (\%) }\end{array}$ & $\begin{array}{l}p N P- \\
\text { N'acethylglucoseaminid } \\
\text { ase (\%) }\end{array}$ & $\begin{array}{l}\text { Dopamineoxyda } \\
\text { se } \\
(\%)\end{array}$ & $\begin{array}{l}\text { Pyrocatécholoxyda } \\
\text { se } \\
(\%)\end{array}$ \\
\hline None & 0 & 100 & 100 & 100 & 100 \\
\hline \multirow[b]{2}{*}{$\mathrm{Ca}^{2+}$} & 1 & $87.74 \pm 2.15$ & $121.09 \pm 3.45$ & $144.44 \pm 5.41$ & $155.22 \pm 3.15$ \\
\hline & 5 & $88.44 \pm 0.43$ & $108.84 \pm 2.08$ & $129.73 \pm 2.08$ & $201.49 \pm 3.37$ \\
\hline \multirow[b]{2}{*}{$\mathrm{K}^{+}$} & 1 & $110.86 \pm 3.9$ & $108.16 \pm 2.17$ & $129.73 \pm 2.47$ & $117.16 \pm 2.21$ \\
\hline & 5 & $101.11 \pm 1.31$ & $101.36 \pm 1.65$ & $92.79 \pm 2.01$ & $119.16 \pm 2.08$ \\
\hline \multirow[b]{2}{*}{$\mathrm{Cu}^{2+}$} & 1 & $44.84 \pm 0.06$ & $29.93 \pm 0.23$ & $34.68 \pm 0.05$ & $30.6 \pm 2.04$ \\
\hline & 5 & $34.81 \pm 0.22$ & $40.81 \pm 1.13$ & 0 & $63.42 \pm 1.34$ \\
\hline \multirow[b]{2}{*}{$\mathrm{Mg}^{2+}$} & 1 & $122.42 \pm 3.67$ & $107.48 \pm 1.41$ & $120.27 \pm 1.39$ & $133.58 \pm 3.32$ \\
\hline & 5 & $130.22 \pm 2.18$ & $104.08 \pm 2.16$ & $145.05 \pm 2.27$ & $158.21 \pm 3.45$ \\
\hline \multirow[b]{2}{*}{$\mathrm{Zn}^{2+}$} & 1 & $89.41 \pm 2.81$ & $132.65 \pm 3.25$ & $81.99 \pm 1.17$ & $19.4 \pm 0.37$ \\
\hline & 5 & $96.1 \pm 1.17$ & $146.25 \pm 1.22$ & $13.06 \pm 0.22$ & $14.92 \pm 0.12$ \\
\hline \multirow[b]{2}{*}{ SDS } & 1 & $6.68 \pm 0.02$ & $153.06 \pm 3.49$ & $9.01 \pm 0.08$ & $62.69 \pm 1.14$ \\
\hline & 5 & 0 & $251.06 \pm 3.18$ & $13.06 \pm 1.17$ & $140.3 \pm 2.42$ \\
\hline \multirow[b]{2}{*}{ EDTA } & 1 & $167.54 \pm 3.56$ & $156.46 \pm 2.11$ & $63.96 \pm 0.35$ & $26.86 \pm 1.16$ \\
\hline & 5 & $135.93 \pm 2.16$ & $129.93 \pm 2.04$ & $39.4 \pm 0.43$ & $34.33 \pm 1.09$ \\
\hline
\end{tabular}

\section{Discussion}

Plant cells contain numerous substrates which are transformed by the action of endogenous enzymes. These enzymes are responsible for most of the ripening and senescence processes of fruit and vegetables, making their preservation problematic. The screening of enzyme activities and the determination of optimal $\mathrm{pH}$ and hydrolysis temperature conditions in the berries of Solanum aethiopicum cultivar "Klongbo" was the subject of this study. Thus, among the enzymes sought, phophatasic, acetylase, dopaminase and pyrochatecholasic activities were found to be dominant (Figure 2). It has been shown that pbosphatase is involved in the energy supply, phosphorylation and dephosphorylation of sugars during post-harvest metabolism in plants [13]. Indeed, the significant hydrolysis of pyrophosphate by phosphatase would provide phosphate groups which would participate in the degradation of starch by the phosphorylase route. This screening shows that amylase is the dominant enzymatic activity for the osidic ones. Among the polyphenoloxidase activities, dopamineoxydase and pyrachatecholoxydase proved to be dominant. Polyphenoloxidases catalyse the oxidation of both o-diphenolic substrates (dopamine, pyrocatechol) and triphenol (pyrogallol). Polyphenoloxidases extracted from Solanum aethiopicum berries have no affinity for monophenols (Ltyrosine and phenylalanine). Similar results have been obtained by several authors where ortho-diphenols and triphenols were the best substrates compared to monophenols [14,15]. The presence of polyphenoloxidase activity is an indicator of cellular activity in fruits and vegetables [16]. Thus, like many vegetables, the berries of Solanum aethiopicum "Klongbo" contain polyphenoloxidase activities (PPO). The work of [17] Dan (2014) on the berries of Solanum anguivi Lam harvested in Côte d'Ivoire has shown that polyphenoloxidase activities are present in the plant cells of aubergines. According to Vamos-Vigyazo [18] these substances play a very important role in the polymerisation of quinones by creating insoluble polymers that act as a barrier against infections. The study of the optimal conditions of hydrolytic activity of the berries of Solanum aethiopicum cultivar "Klongbo" shows a diversity of reactivity according to the substrate used. The dopamineoxydase activities show their optimum $\mathrm{pH}$ in a basic environment. Two peaks are obtained, pH 9.6 in the glycine-hydroxide buffer and pH 8 (81.21\% Relative Activity) in the potassium phosphate buffer. The pyrocatecholoxydasic enzyme activities are also maximal in the glycine hydroxide buffer at pH 9.0. The work of Chuanjuna et al, [19], shows that the acidic medium inhibits the browning of Phalaenopsis Explants. This experiment proves that some PPOs react outside acidic $\mathrm{pH}$ and the change in hydrogen potential could inhibit their activity. The 
value of the optimum oxidation $\mathrm{pH}$ determined is within the general range of the optimum $\mathrm{pH}$ values of polyphenoloxydases, which are between 4.0 and $9[20,21]$. The $\mathrm{pH}$ is an important factor in the speed of reactions. Indeed, outside the area of PPO activity, the oxidation reaction is slower and can be inhibited by an acidification of the culture medium. This acidification of the $\mathrm{pH}$ outside the range of PPO activity can help to overcome the damage caused by browning. The $\mathrm{pH}$ of $p$-NP- N'Acethylglucosaminidasic activities is acidic (pH 5.6-6.6, citrate-phosphate buffer) and that of $p$-NP-Phosphatasics shows two peaks of activity with the glycine-hydroxide buffer $\mathrm{pH} 8.0$ and the acetate buffer pH 5.0 (Figure 3). These two peaks of activity could be explained by the fact that the enzymatic crude extract has a heterogeneous medium expressing enzymatic protein isoforms. The berries of Solanum aethiopicum cultivar "Klongbo" have optimal mesophilic hydrolysis temperatures for phosphate and acetylase activity, $50{ }^{\circ} \mathrm{C}$ and $45^{\circ} \mathrm{C}$ respectively (Figure 4). On the other hand, the optimal hydrolysis temperatures for dopamineoxydase and pyrocholoxydase activities are psychrophilic $\left(10^{\circ} \mathrm{C}\right)$. It should be noted that the control of storage temperatures can have significant effects on enzymatic activities.

Enzymes are known to be catalysts for various biochemical or biological reactions. It has been shown that the reactivity of some of them is induced or improved either by the presence of non-protein molecules or by that of metal ions. In chloroplast, many species of ions are present $\left(\mathrm{H}^{+}, \mathrm{K}^{+}, \mathrm{Na}^{2+}, \mathrm{Cl}^{-}, \mathrm{Cu}^{2+}, \mathrm{Mg}^{2+}, \mathrm{Zn}^{2+}, \mathrm{Mn}^{+} \ldots\right)$. The presence of ions in plant substances requires the testing of some monovalent and divalent ions on raw extracts of Solanum aethiopicum cultivar "Klongbo" berries. $\mathrm{Cu}^{2+}$ ions inhibited all the enzymatic activities tested and more particularly $\mathrm{Zn}^{2+}$ ions for polyphenoloxidase activities (Tableau 1). Like many copper metalloproteins [22, 23, 24], those of the berries of Solanum aethiopicum cultivar "Klongbo" do not require the action of $\mathrm{Cu}^{2+}$ ions for their oxidase activity. EDTA (Ethylenediaminetetraacetate) is an ion chelator. This compound has an inhibitory effect on polyphenoloxidase activities (dopamineoxydase and pyrocholoxydase), which could possibly suggest metalloenzymes. On the other hand, EDTA has an inhibitory effect on phosphatasic and N'Acethylglucosaminidasic activities. As for Sodium Dodecyl Sulphate (SDS) which has an uncoiling effect on enzymatic proteins by cutting the thiol bridges (SH) has no effect on $\mathrm{N}$ 'acetylasic activities contrary to the enzymes investigated in this study. This result suggests that the $\mathrm{N}$-acetylase enzyme protein of the berries of Solanum aethiopicum cultivar "Klongbo" could be monomeric and those of the polyphenoloxyadse and phosphatase more than two monomers.

\section{Conclusion}

The general objective of our study is the post-harvest conservation of berries of Solanum aethiopicum cultivar "Klongbo". Specifically, in this experiment, the screening of the hydrolytic and oxidative activities allowed us to highlight the phophatasic, N'Acethylglucosaminidasic, dopamineoxydasic, and pyrocatecholoxydasic activities in the raw enzymatic extract. Phosphatasic enzymatic proteins express their maximum activity in a basic and mesophilic environment. Also, the polyphenoloxidase activities have an optimum basic $\mathrm{pH}$ not against their optimum temperature is psychrophilic. The control of the activities of these biocatalysts could be an asset in the post-harvest conservation of berries of Solanum aethiopicum cultivar "Klongbo".

\section{Compliance with ethical standards}

\section{Disclosure of conflict of interest}

All authors declare that they have no conflict of interest.

\section{References}

[1] Daunay MC, Chaput MH, Sihachakr D, Allot M, Vedel F, Ducreux G. Production and characterization of fertile somatic hybrids of eggplant (Solanum melongena L.) with Solanum aethiopicum L. Theoretical and Applied Genetics. 1993 Feb 1; 85(6-7):841-50.

[2] Grubben G, Denton 0. Ressources Végétales de L'Afrique Tropicale 2 (PROTA); légume, Wageningen, Pays- Bas. 2004; 548- 553.

[3] CNRA. Bien cultiver l'aubergine en Cote dlvoire. Fiche. 2013; 23.

[4] Lester RN, Hakiza JJH, Stavropoulos N, Teixiera MM. Variation patterns in the African Scarlet eggplant, Solanum aethiopicum L. In infraspecific of wild and cultivated plants. Ed. B.T Styles Oxford, oxford University Press. 1986.

[5] Fondio L, Kouamé C, N'ZI JC, Mahyao A, Agbo E, Djidji AH. Survey of Indigenous Leafy Vegetable in the Urban and Peri-urban Areas of Côte d'Ivoire. In: M.L. Chadha et al. (Eds.). Indigenous Vegetables and Legumes: prospects for 
fighting Poverty, Hunger and Malnutrition. Proceedings of the 1 $1^{\text {st }}$ International Conference, ICRISAT Campus, Patancheru Hyderabad, India, December 12 - 15, 2006. Drukkerij Geers, Gent, Belgium. 2007; 287- 289.

[6] Stevels JMC. Solanaceae. In légumes traditionnels du Cameroun, une étude agrobotanique. Wageningen Agric. Univ. Papers. 1990; 90-1: 201-220.

[7] Apak R, Güçlü K, Demirata B, Ôzyürek M, EsinÇelik S, Bektasoglu B, Berker K, Ôzyurt D. Comparative Evaluation of Various Total Antioxidant Capacity Assays Applied to Phenolic Compounds with the CUPRAC Assay. Molecules. 2007; 12: 1496-1547.

[8] Trèche $\mathrm{S}$. Valeur nutritionnelle des ignames. L'igname plante séculaire et culture d'avenir. Actes du séminaire international Ctrad-Inra-Orstrorn-Coraf, 3-6 juin 1997, Montpellier (France). Edited by: Berthaud J. Bricas N., Marchand J. L. CIRAD. Montpellier, France. 1997; 305-321.

[9] De Rigal D. Recherches sur l'inhibition du brunissement enzymatique. Utilisation de préparations enzymatiques, substitutives aux sulfites. Thèse de doctorat. Université de droit, d'économie et des sciences d'Aix Marseille III $2001 ; 173$.

[10] Brat P. Application du procédé de flash détente sous vide aux fruits tropicaux et méditerranéens pour la préparation de purée et huiles essentielles. Thèse de Doctorat, Université de la Réunion, France. 2001; 137.

[11] Bernfeld P. Amylase p and a. (Assay method), in methods in enzymology I, Colowick and Kaplan, Ed., Academic press, New York. 1955; 149-154.

[12] Cong R, Sun W, Liu G. Purification and characterization of phenoloxidase from clam Ruditapes philippinarum. Fish and Shellfish Immunology. 2005; 18: 61-70.

[13] Hamdan RI. Purification et propriétés physico-chimiques de l'amidon phosphorylase d'igname (Dioscorea cayenesis). Thèse de doctorat 3e cycle. Univ. Nationale de Côte d'Ivoire. 1987; 89.

[14] Dincer B, Colak A, Aydin N, Kadioglu A. Güner S. Characterization of polyphenoloxidase from medlar fruits (Mespilus germanica L. Rosaceae). Food Chemistry. 2002; 77: 1-7.

[15] Adeosun 0. Preliminary studies on polyphenol oxidase activity in plantain (Musa paradisiaca) cultivars. African Journal of Agricultural Research. 2013; 8(4): 266-369.

[16] Cheftel JC, Cheftel H. Introduction à la biochimie et à la thermique des aliments. Ed. TEC. et DOC. 1992; 381.

[17] Dan CG. Evolution des paramètres biochimiques et physicofonctionnels des baies de Solanum anguivi Lam récoltées en Côte d'Ivoire au cours du mûrissement. Thèse université Nangui Abrogoua. 2014; 170.

[18] Vamos-Vigyazo L. Polyphenol oxidase and peroxidase in fruits and vegetables. Criticel Reviews in Food Science and Nutrition. 1981; 15: 49-127.

[19] Chuanjuna XU, Zhiweib R, Lingb LI, Biyua Z, Junmeia H, Wena H, Oua HU. The Effects of Polyphenol Oxidase and Cycloheximide on the Early Stage of Browning in Phalaenopsis explants. Hortic Plant J. 2015; 1(3): 172-180.

[20] Chevalier T, Rigal D, Mbeguie-A-Mbeguie D, Gauillard F, Richard-forget F, Filslycaon BR. Molecular cloning and characterization of apricot fruit polyphenol oxidase. Plant Physiology. 1999; 119: 1261-1269.

[21] Gnangui SN, Niamke SL, Kouame LP. Sorne characteristics of polyphenoloxidase purified from edible yam (Dioscorea cayenensis-rotundata cv. Longbô) cultivated in Côte d'Ivoire. Journal of Food Sciences and Technology. 2009; 44: 2005-2012.

[22] Siegbahn PEM. The catalytic cycle of catechol oxidase. Journal of Biological Inorganic Chemistry. 2004; 9: 577590.

[23] Sanjeev KD, Sarad KM. Purification and Biochemica1 Characterization of Ionically Unbound Polyphenol Oxidase from Musa paradisiaca Leaf. Preparat. Applied Biochemistry and Biotechnology. 2011; 41(2): 187-200.

[24] YAPI JC. Etude du brunissement enzymatique et caractérisation des enzymatique polyphénoloxydases du tubercule de l'igname Dioscorea cayenensis rotundata (cultivar "Kponan "). Thèse université Nangui Abrogoua. $2015 ; 145$. 